\title{
The Concept Design for Adaptation of Climate Change Through Integrated and Sustainable Flood Infrastructure in the Coastal Area of Pekalongan, Indonesia
}

\author{
Suyudi Akbari Habibi ${ }^{*}$, Arif Darmawan PribadiA , Jessica Elisabeth Sitorus ${ }^{\mathrm{A}}$ \\ Received: February 13, 2021 | Revised: May 25, 2021 | Accepted: May 27, 2021 \\ doi: 10.5937/gp25-30852
}

\begin{abstract}
The coastal area of Pekalongan, especially the estuary area of the Banger River, Loji River, and Gabus River, are often experiencing to tidal floods. Tidal Floods that occur pose a great risk due to the sedimentation of river mouths and floods from the watershed to the coastal area of Pekalongan. This study aims to assess the impact of climate change on flood frequency patterns and the contribution of each sub-watershed to the total discharge that occurs, as well as to analyze the effect of increasing sea level that occurs in the coastal area of Pekalongan. The method used in this research hydro-meteorological, hydraulic, and hydrodynamics two-dimensional analysis. The results showed that the climate change that occurred in the coastal area of Pekalongan was indicated by an increase in the average temperature of about $1^{\circ}$ Celsius and the trend towards maximum yearly precipitationthat occurred during a period of twenty years had increased (2000-2019 period). An Increasing temperature that occurs has a significant risk to sea-level rise and increasing uncertainty hydrometeorological hazard (tidal flooding). Recommendations from this study are structuring the drainage system based on an integrated landscape arrangement concept to improve the economy, tourism, social, and environment to achieve sustainable coastal infrastructure.
\end{abstract}

Keywords: TidalFloods; Sea Water Rise, Pekalongan

\section{Introduction}

Pekalongan is a city that grows and develops in the north coast of Central Java. Pekalongan has been potential to be impacted by the sea level rise and flooding at the mouth of the Banger River, Loji River, Gabus River. According to the results of a study conducted by (River Basin Organization Pemali Jauna, 2020) the area of the flood inundation that occurred in the northern coast of Pekalongan, namely 458.3 ha which inundated residential areas, agricultural land and road and bridge infrastructure which are the main logistics route in the northern region of Central Java. The tidal flood that occurred caused economic losses and disrupted community activities on the coast of Pekalongan. Handling of tidal flood that has occurred has been carried out with a pump system in areas that are experiencing inundation, but it is still not effective in solving the rob flood problem that occurs. Approach that can be taken to solve the tidal flooding on the north coast of Pekalongan is the arrangement of the coastal area of Pekalongan using the concept of sustainable development.

\footnotetext{
A Directorat General of Water Resources, Ministry of Public Works and Housing, Republic of Indonesia; suyudiakbarihabibi2019@gmail.com, arifdpteknik@gmail.com, jessicaelisabeth860@yahoo.co.id

* Corresponding author: Suyudi Akbari Habibi, e-mail: suyudiakbarihabibi2019@gmail.com
} 

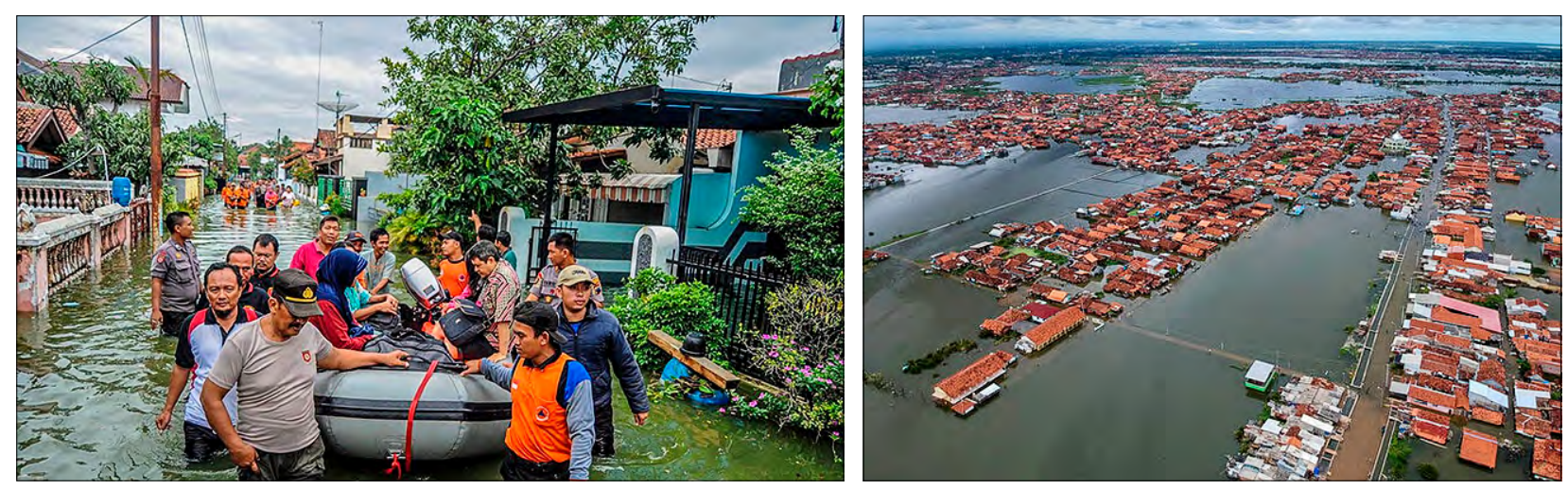

Figure 1. Flood Conditions on the Coast of Pekalongan Coast Source: jatengtribunnews.com (26 February 2020)

The old development principles need to be changed so that infrastructure development can refer to the new environmental management principles that are more environmentally friendly. On the other hand, every infrastructure development must look at social factors related to society as well as other impacts caused by infrastructure development, so that it will add to the economic value resulting from the arrangement of the coastal area Pekalongan.
Based on these facts, this study aims to determine the impact of tidal flood in the coastal area of Pekalongan and provide adaptive efforts to handle tidal flood through regional structuring and sustainable coastal infrastructure development. Sustainable zoning and development of coastal infrastructure are integrated with various existing sectors such as tourism and agriculture to improve the economy.

\section{Methodology}

\section{Study Locations}

The city of Pekalongan is located 6 $650^{\prime} 42^{\prime \prime}-6^{\circ} 55^{\prime} 44^{\prime \prime}$

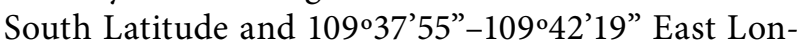
gitude on the northern coast of Java. The entire area of Pekalongan City is included in the integrated watershed, covering the Sengkarang watershed, the Kupang watershed, and the Susukan watershed. Based on data from the Minister of Public Works and Housing Regulation No. 04 of 2015, it is known that the location of the Pekalongan tidal flood inundation is in the Pemali Comal river area. The research location is in the Kupang Watershed, which has an area of $234,048 \mathrm{~km}^{2}$ with a length of the main river that is $53.23 \mathrm{~km}$. The upstream of the Kupang water-

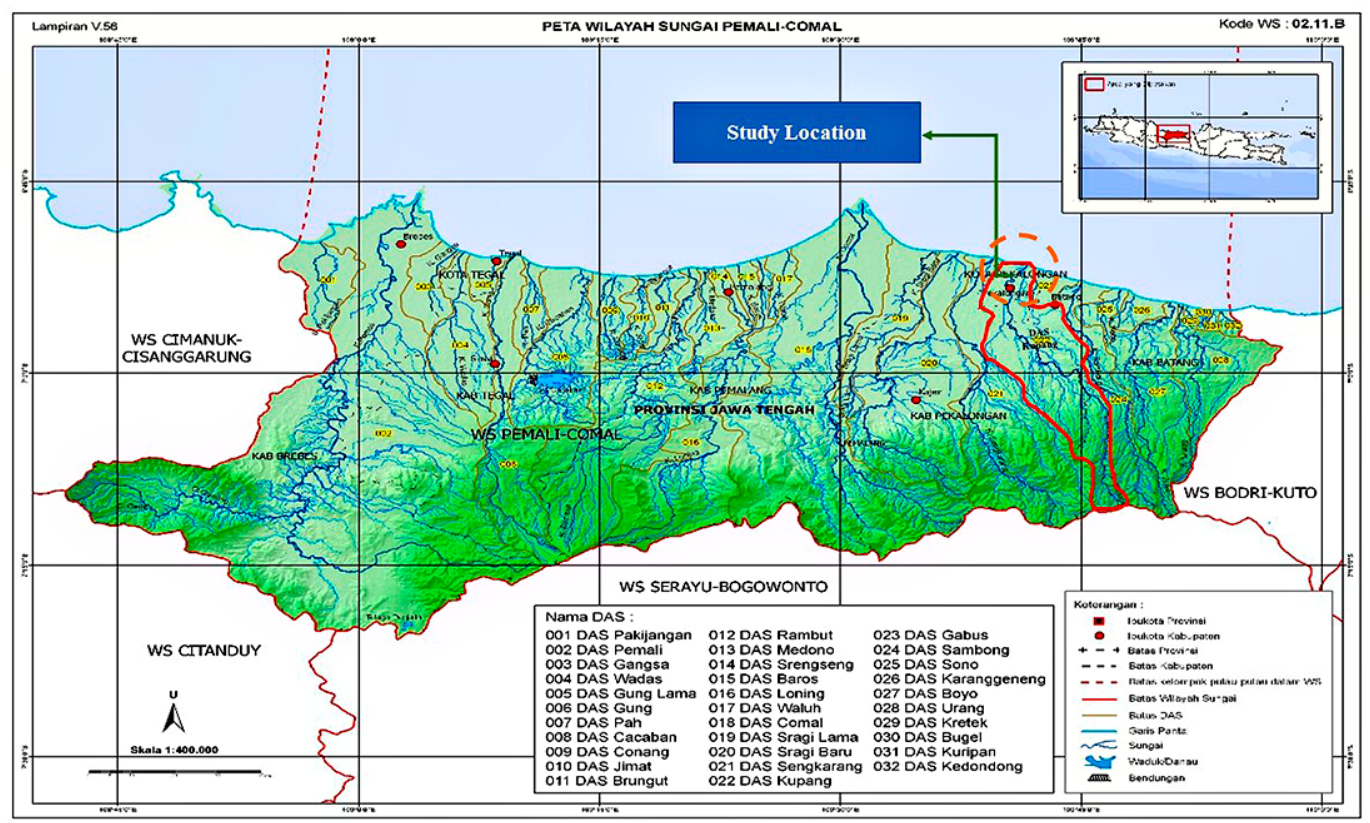

Figure 2. Map of Study Location for the Kupang Watershed in the Pemali Comal River Basin 


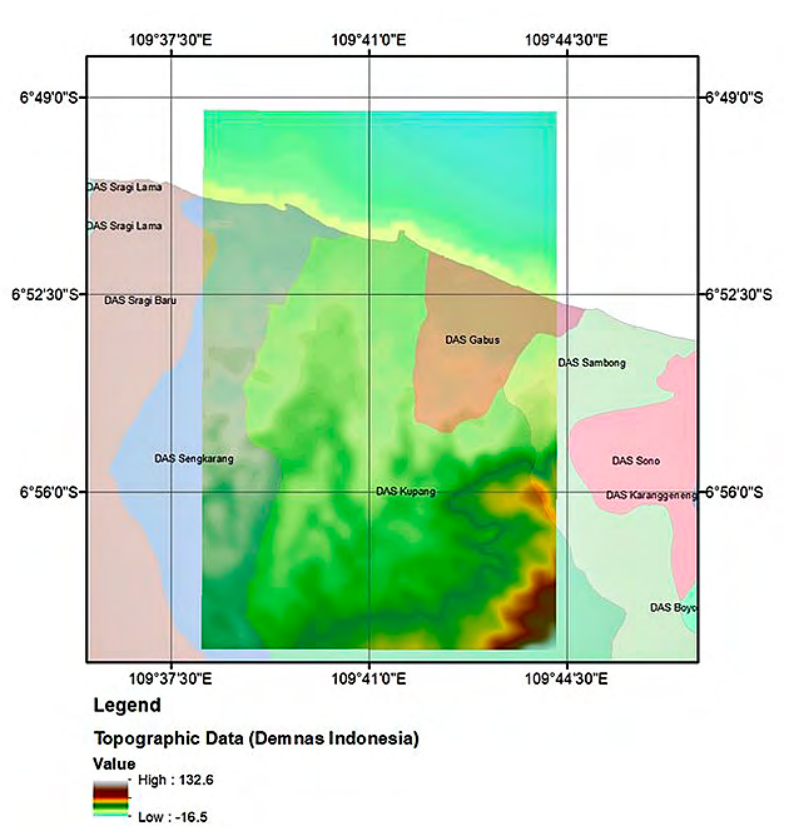

Figure 3. Topographic data Location Area

shed is in Pekalongan Regency and the downstream in Pekalongan City.

Based on the results of the inventory of tidal flood inundation data that occurred in Pekalongan (River Basin Organization Pemali Juana, 2019), there were four affected villages with a total inundation area of 458.3 hectares with a variation flood inundation height varying from $20 \mathrm{~cm}$ to 1 meter. The locations affected by the flood in Pekalongan are:

- Kendang Panjang 26 hectares

- Panjang Wetan 69,3 hectares

- Krepyak Lor 163 hectares

- Degayu 227 hectares
Based on existing topographic data, the depth of the waters' study location ranges from -16.5 meters and the maximum land height is 132.6 meters. This topographic data is very significant to be used, especially for interpreting data and studying floods on the coast of Pekalongan.

\section{Methodology}

This research begins by collecting secondary data from several agencies such as Meteorological, Climatological, and Geophysical Agency in Indonesia, River Basin Organization Pemali Juana Pemali Juana. The data analysis carried out was climate change analysis using data for the last 20 years (2000-2019), hydrological analysis, and flood modeling, coastal analysis and modeling. In performing analysis and handling design using ArcGIS, HEC-RAS, Delft 3D, AutoCAD applications. The research flow in this study is shown in Figure 2. Meanwhile, the concept of beach modeling using the hydrodynamic Delft 3D model is shown in Figure 5.

In this study quantitative research method was used are secondary data. The analyzes included: i) hydrological-meteorological analysis, ii) two-dimensional hydraulic analysis, iii) two-dimensional hydrodynamic analysis of the Pekalongan coastline, iv), and a map of the inundation depth distribution map due to climate change. Modeling was carried out in 2 scenarios, namely the existing condition scenario in 2020 and the scenario in the future condition, namely in 2070 .

The first thing to do is to change the National Demnas data in the form of terrain into a GeoTIFF. After that, a meshing is made with the involvement of $20 \mathrm{~m} \times 20 \mathrm{~m}$, and the boundary conditions are made

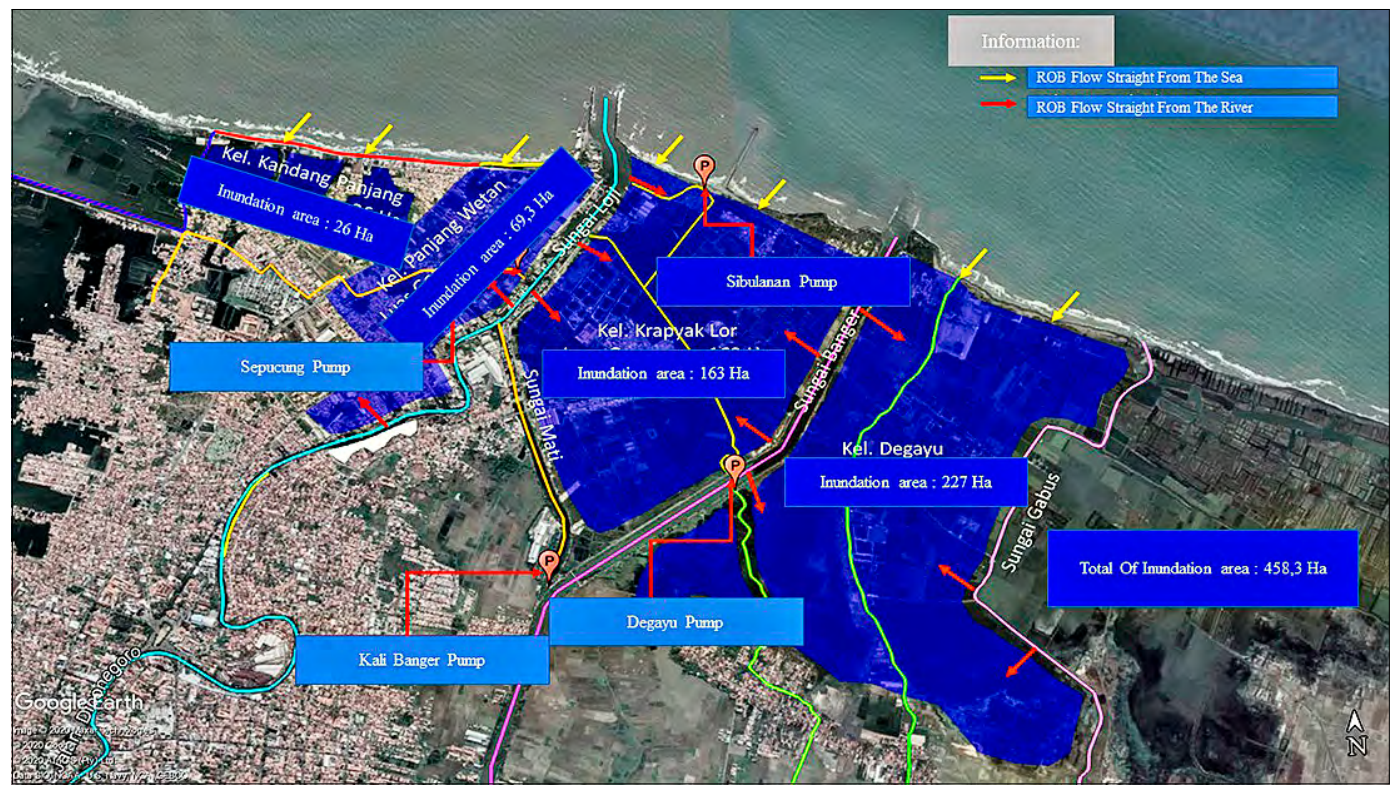

Figure 4. Inundation Area and Existing Pump System for Tidal Floods 


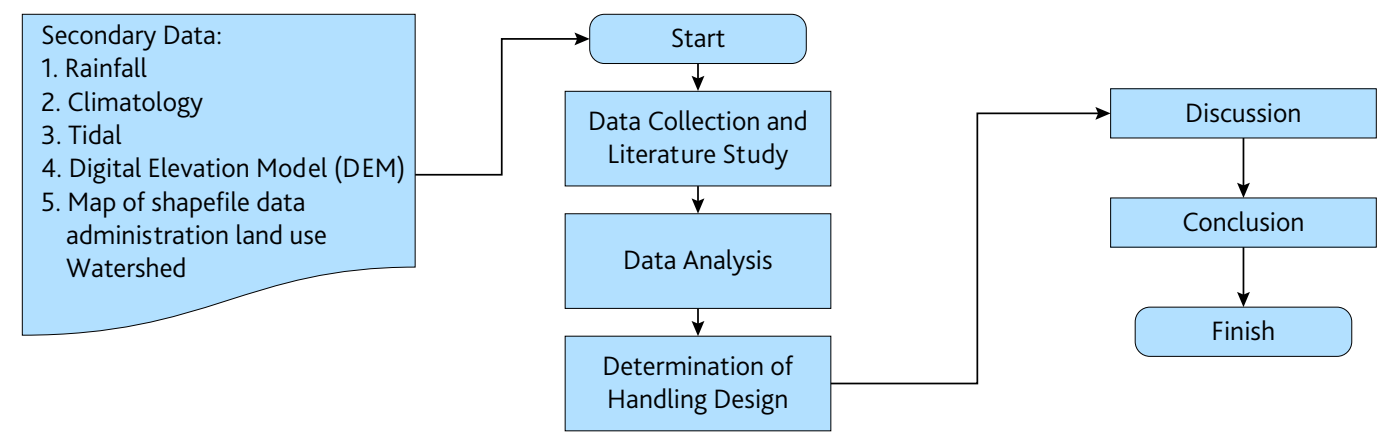

Figure 5. Research Flow

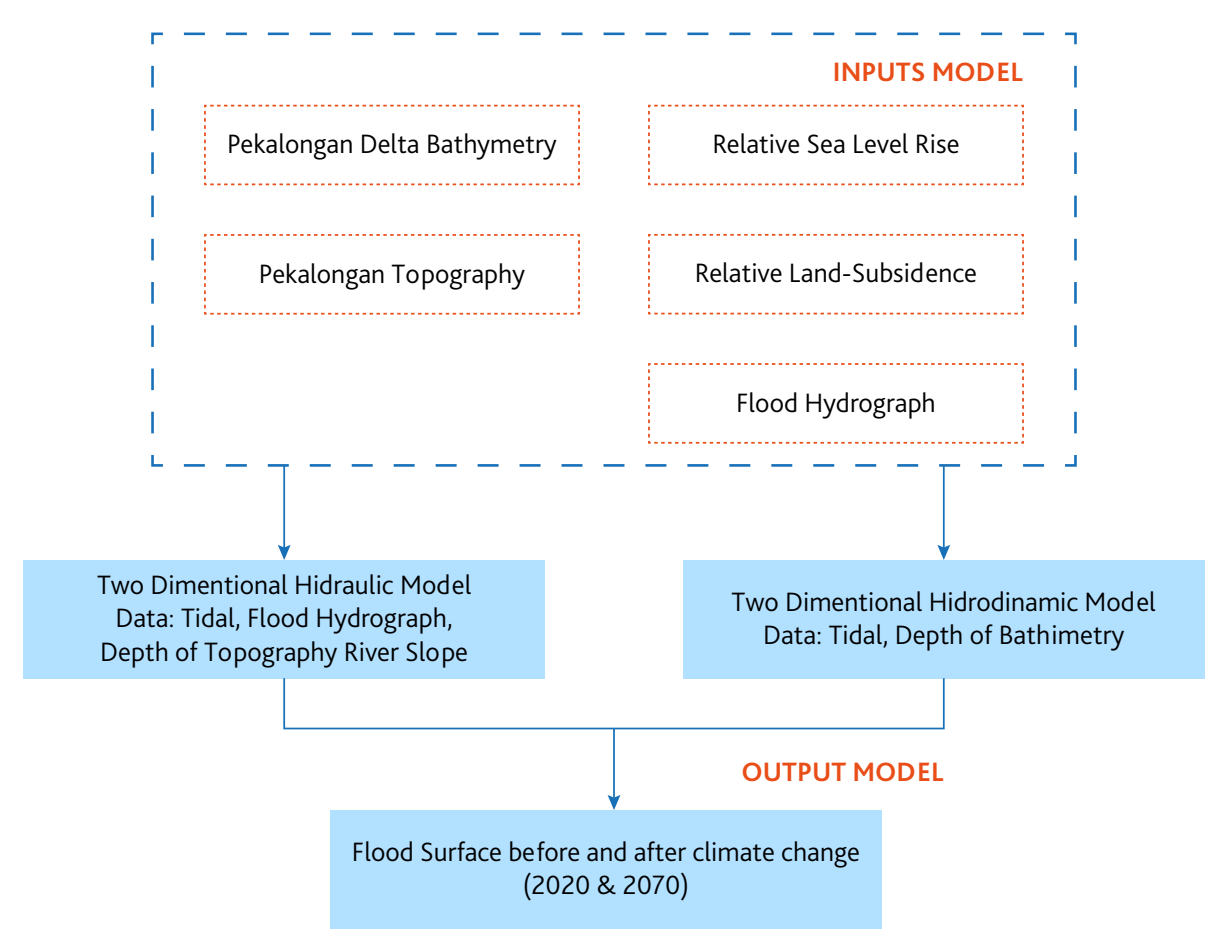

Figure 6. The methodology of two-dimensional hydraulic and hydrodynamic modeling

from upstream and downstream. After that, the modeling was run and flood inundation was obtained. The flood inundation modeling is limited to the downstream of the river around the Pekalongan coast. The timestep used in modeling is about 5 seconds. The timestep selection is crucial in the success of modeling. In this study, the modeling carried out was not specific to field safeguards but only to assess the potential for existing flooding. Further study of floods will require more data, especially data on the distribution of floods that occur based on observations made by related agencies,

The Parameter of modeling as following:

- Manning Roghness value: 0.025 (clean, straight, full stage, no rifts or deep channel;)

- The boundary condition is divided into Upstream boundary and downstream boundary. Upstream boundary using flow hydrograph and Downstream boundary using maximum tidal elevation.

\section{Flood Discharge Calculation}

To estimate the amount of peak runoff $(\mathrm{QP})$, a synthetic unit hydrograph (HSS) is used which is based on the physical characteristics of the watershed, this is because there is no river discharge observation data that can be used to make a unit hydrograph. In making the hydrograph of the synthetic unit previously calculated the rain plan that will be used incalculating the flood discharge. The HSS used is the Nakayasu method (Irawan, 2020) to determine the peak discharge that occurs at the research location. So that the peak discharge magnitude can be used in modeling the flood in the study area. The equations used are as follows:

Interval Time $\left(T_{g}\right)$ and Peak Time $\left(T_{p}\right)$

$$
T_{g}=0.5279+0.058 \mathrm{~L} \text { to } \mathrm{L}>15 \mathrm{~km}
$$

$T_{g}=0.21 L^{0.7}$ to $\mathrm{L}<15 \mathrm{~km}$ 
$T_{p}=T_{g}+0.8 T_{r}$

Where:

- $T_{g}=$ delay time (hours)

- $T_{r}=$ unit of time of rainfall (hours)

- $T_{p}=$ peak time (hours)

- $L=$ length of river

Peak discharge for effective rain is $1 \mathrm{~mm}$ in an area of $\mathrm{A} \mathrm{km}^{2}$

$Q_{p}=\frac{A R_{e}}{3.6 T_{p}+T_{0.3}}$

Where:

- $Q_{p}=$ peak flood discharge $\left(\mathrm{m}^{3} / \mathrm{s}\right)$

- $R_{e}=$ effective rain unit $(1 \mathrm{~mm})$

- $T_{p}=$ time from the beginning of rain to the peak of the flood (hours)

- $A=$ the area of the watershed oto the outlet

- $T_{0.3}=$ time of discharge reduction, from peak to $30 \%$

- $\alpha=$ hydrograph parameter

Where:

- $\alpha=2.0$ in the usual drainage area

- $\alpha=1.5$ on the ascending part the hydrograph is slow and fast descending

- $\alpha=3.0$ on the ascending part of the hydrograph fast and slow descending

The equation for the basic form of hydrograph for the hydrograph for the Nakayasu unit consists of four curve segments which are expressed by the following equation:

When the curve rises: $0<\mathrm{t}<$

$Q_{(t)}=\left(\frac{t}{T_{p}}\right)^{2.4}$

Where:

- $Q_{(t)}=$ runoff before seeking peak discharge $\left(\mathrm{m}^{3} / \mathrm{s}\right)$

- $t=$ time (hour)

When the curve declines:

Value hose: $\mathrm{t} \leq\left(T_{p}+T_{0.3}\right)$

$Q_{(t)}=Q_{p} 0.3^{\left(\frac{t T_{p}}{T_{0.3}}\right)}$

Value hose: $\left(T_{p}+T_{0.3}\right) \leq t \leq\left(T_{p}+T_{0.3}+1.5 \mathrm{~T}_{0.3}\right)$

$Q_{(t)}=Q_{p} 0.3^{\left(\frac{t T_{p}+0.5 T_{0.3}}{1.5 T_{0.3}}\right)}$

Value hose: $t \geq\left(T_{p}+T_{0.3}+1.5 \mathrm{~T}_{0.3}\right)$
$Q_{(t)}=Q_{p} 0.3^{\left(\frac{t T_{p}+0.5 T_{0.3}}{2 T_{0.3}}\right)}$

\section{Coastal Hydrodynamic Analysis}

\section{a) Governing Equation of Hydraulic Model}

The software used for two-dimensional flow modeling is HEC-RAS (River Analysis System). The regulatory equations used for $2 \mathrm{D}$ HEC-RAS modeling are the conservation equation and the continuity equation. Assuming an incompressible flow, the mass conservation equation (continuity) in the form of unsteady flow is as follows:

$\frac{\partial H}{\partial t}+\frac{\partial(h u)}{\partial x}+\frac{\partial(h v)}{\partial y}+q=0$

Where $t$ is time, $\mathrm{u}$ and $\mathrm{v}$ are the velocity components in the $\mathrm{x}$ direction and in the $\mathrm{y}$ and $\mathrm{q}$ direction are the source / link flux forms (HEC-RAS Manual Reference, 2018). Two-dimensional flow modeling also applies the Navier-Stoke momentun equation for shallow flows. The momentum equation that applies is as follows:

$\frac{\partial v}{\partial t}+u \frac{\partial v}{\partial x}+v \frac{\partial v}{\partial y}=-g \frac{\partial H}{\partial x}+v i\left(\frac{\partial^{2} v}{\partial x^{2}}+\frac{\partial^{2} v}{\partial y^{2}}\right)-c_{f} u+f v$

$\frac{\partial u}{\partial t}+u \frac{\partial u}{\partial x}+v \frac{\partial u}{\partial y}=-g \frac{\partial H}{\partial x}+v i\left(\frac{\partial^{2} u}{\partial x^{2}}+\frac{\partial^{2} u}{\partial y^{2}}\right)-c_{f} u+f v$

$c_{f}=\frac{n^{2} g|V|}{R^{\frac{4}{3}}}$

$f=2 \omega \sin \phi$

Where $\mathrm{u}$ and $\mathrm{v}$ are velocities in the Cartesian direction $(\mathrm{m} / \mathrm{s}), \mathrm{g}$ is the acceleration due to gravity $\left(\mathrm{m}^{2} / \mathrm{s}\right)$, vi is the horizontal efficiency of eddy viscosity, cf is the friction coefficient, $\mathrm{R}$ is the hydraulic radius and $\mathrm{f}$ is the Coriolis parameter (HEC-RAS Reference Manual, 2018). The momentum equation in the form of a simple and differential diffusion wave is as follows:

$\frac{\partial H}{\partial t}-\nabla \cdot \beta \nabla H+q=0$

$\beta=\frac{(R(H))^{\frac{5}{3}}}{n|\nabla H|^{\frac{1}{2}}}$ 
$\frac{n^{2}|V| V}{(R(H))^{\frac{4}{3}}}=\nabla H$

$V=\frac{(R(H))^{\frac{2}{3}}}{n} \frac{\nabla H}{|\nabla H|^{\frac{1}{2}}}$

Where $\mathrm{V}$ is the velocity vector $(\mathrm{m} / \mathrm{s}), \mathrm{R}$ is the hydraulic radius, and $\nabla \mathrm{H}$ is the slope of the surface elevation and $\mathrm{n}$ is the empirical value of the Manning coefficient (HEC-RAS Manual Reference, 2018).

\section{b) Governing Equation of Hydrodynamic Model}

Delft3D-FLOW solves the Navier Stokes equation for incompressible fluids, under shallow water and the Boussinesq assumption. In the vertical momentum equation, the acceleration is negligible, which leads to the hydrostatic pressure equation. In the 3D model, the vertical velocity is calculated from the continuity equation (Deltt-3d, 2014).

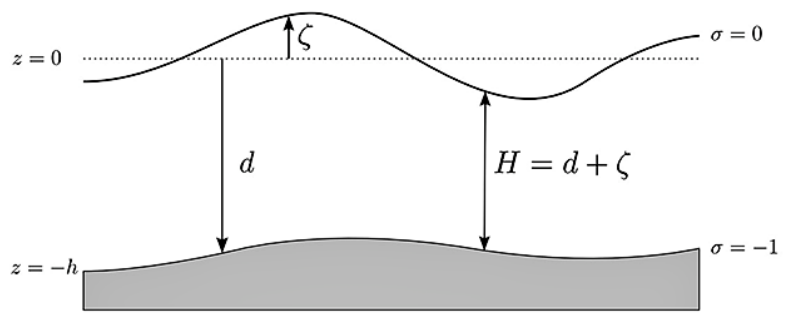

Figure 7. Definition of water level (, depth (h) and total depth $(H)$ (Delft-3d, 2014)

\section{c) Depth-averaged continuity equation}

The depth-averaged continuity equation is given by:

$$
\frac{\partial \zeta}{\partial t}+\frac{1}{\sqrt{G_{\xi \xi}} \sqrt{G_{\eta \eta}}} \frac{\partial(d+\zeta) U \sqrt{G_{\eta \eta}}}{\partial \xi}+\frac{\partial(d+\zeta) V \sqrt{G_{\eta \eta}}}{\partial \eta}=0
$$

Where $U$ and $V$ indicate the depth-average velocities on orthogonal curvilinear grid.

\section{Momentun equations in horizontal direction}

The momentum euqations in $\xi$ and $\eta$ direction area given by:

$$
\begin{aligned}
& \frac{\partial U}{\partial t}+\frac{U}{\sqrt{G_{\xi \xi}}} \frac{\partial U}{\partial \xi}+\frac{V}{\sqrt{G_{\eta \eta}}} \frac{\partial U}{\partial \eta}+\frac{U V}{\sqrt{G_{\xi \xi}} \sqrt{G_{\eta \eta}}} \frac{\partial \sqrt{G_{\xi \xi}}}{\partial \eta}-\frac{V^{2}}{\sqrt{G_{\xi \xi}} \sqrt{G_{\eta \eta}}} \frac{\partial \sqrt{G_{\eta \eta}}}{\partial \xi}-f V \\
& =\frac{1}{\rho_{0} \sqrt{G_{\xi \xi}}} P_{\xi}-\frac{G U \sqrt{U^{2}+V^{2}}}{C_{2 D}^{2}(d+\varsigma)}+F_{\xi}+F_{s \xi}+M_{\xi}
\end{aligned}
$$

The fourth termon the right-hand side represents the effect of secondary flow on the depth average velocities (shear stress by depth-averaging the non-linear acceleration terms).

\section{d) Boundary Condition}

In some timesteps, boundary conditions must be given to all domains (HEC-RAS Manual Reference, 2018), namely:

1. Water level: the value of the water level $\mathrm{H}=\mathrm{Hb}$ is given one side of the boundary condition.

2. Water level gradient: the slope of the water surface $\mathrm{Sb}$ in the normal direction along the boundary. This condition is expressed as follows:

$$
\nabla H \cdot n=S_{b}
$$

Discharge: A Qb debit that is crossed in boundary conditions must be available.

3. The boundary requirement for coastal hydrodynamic modeling is to use the results of tide analysis.

\section{Discussion}

\section{Climate Change Analysis}

Intergovernmental Panel on Climate Change (IPPC) stated that global climate change has resulted in an increase in the average temperature in Indonesia from 0.004 to $0.04 \mathrm{oC}$ per year. An increase in temperature of $1.5 \mathrm{oC}$ results in the risk of sea- level rise, an increase in heavy rainfall which of course will have implications for flooding in coastal areas or downstream of rivers. There are three features of climate change aspects, namely temperature, rain- fall, sea level rise. Climate change studies use climatological data around Pekalongan sourced from the Meteorological, Climatology and Geophysics Agency. The analysis was tcarried out to study the factors that influence climate change at the location, namely temperature and rainfall over a period of 20 years (2000-2019).

Results graph annual average temperature on the north coast of Pekalongan for twenty years (20002019) showed an increase in average temperatures 

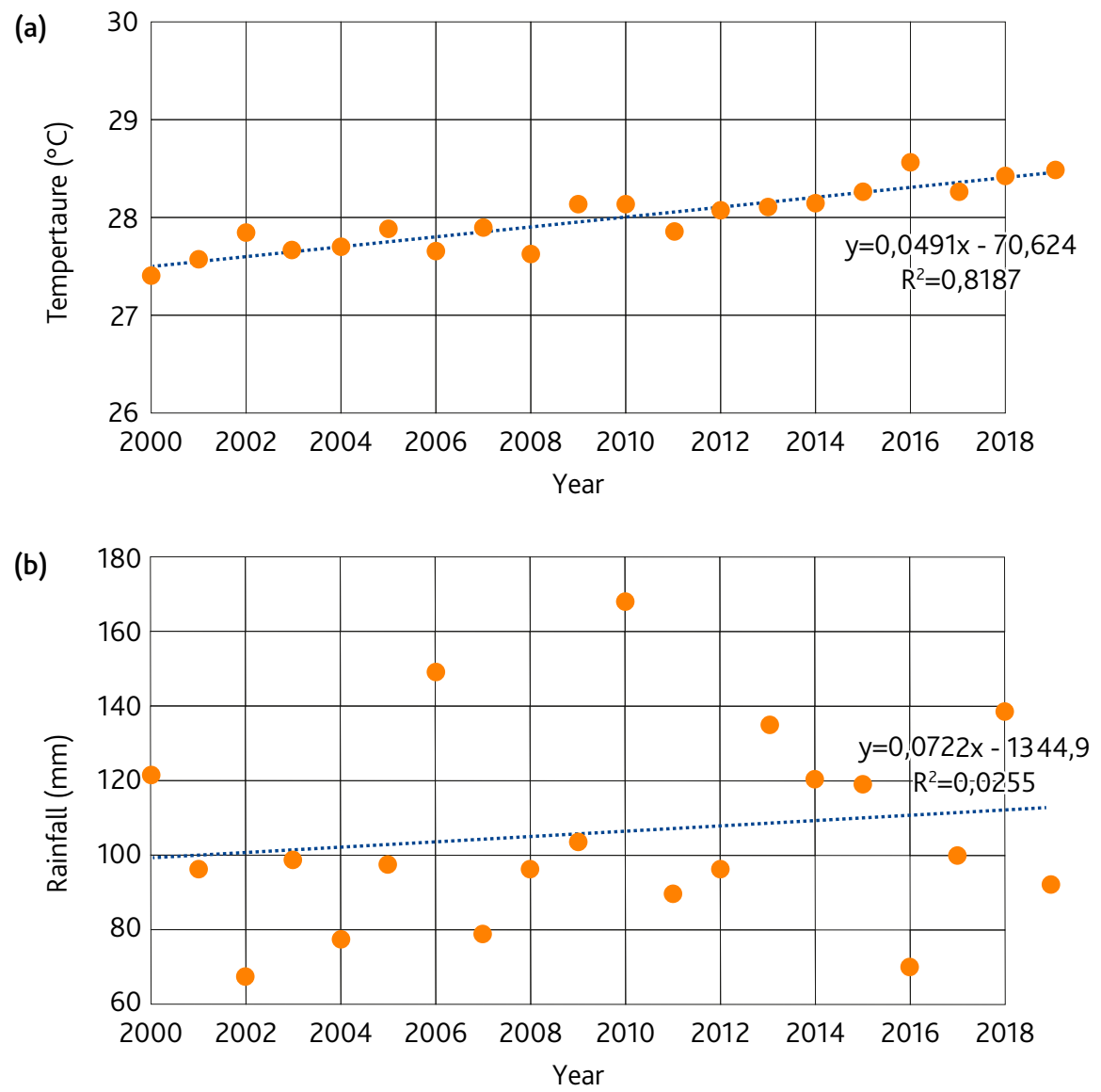

Figure 8. Trend of temperature rise (a) and maximum annual rainfall (b) in the Pekalongan area

around $1^{\circ}$ Celsius and a trend towards maximum rainfall occurring during the period of twenty years has increased (Figure 8).

Climate change also causes changes in rainfall patterns, the total annual rainfall in Pekalongan City for twenty years tends to decline although not significantly (Figure 9), this is in accordance with the results of predictions have been in the Java Island region (Figure 10), where in the location of the City of Peka- longan experiences a trend of changes in rainfall decreasing lightly in the years 2032-2040 (Meteorological, Climatological, and Geophysical Agency, 2020). Meanwhile, the duration of rain will last for a short time with a tendency for rainfall intensity to be higher than normal rainfall, which causes flood disasters (Meiviana, et al., 2015).

The results of studies that have been conducted (Perdana, 2015) show that the north coast of Cen-

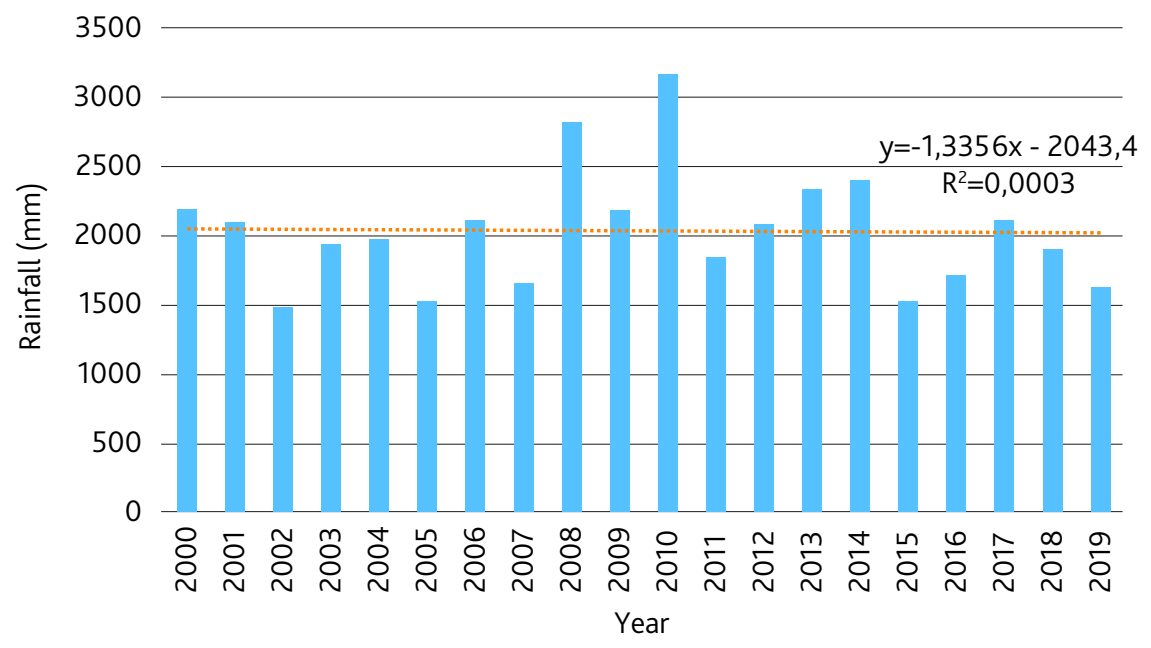

Figure 9. Trend of Total Annual Rainfall in Pekalongan Region (2000-2019 Period) 


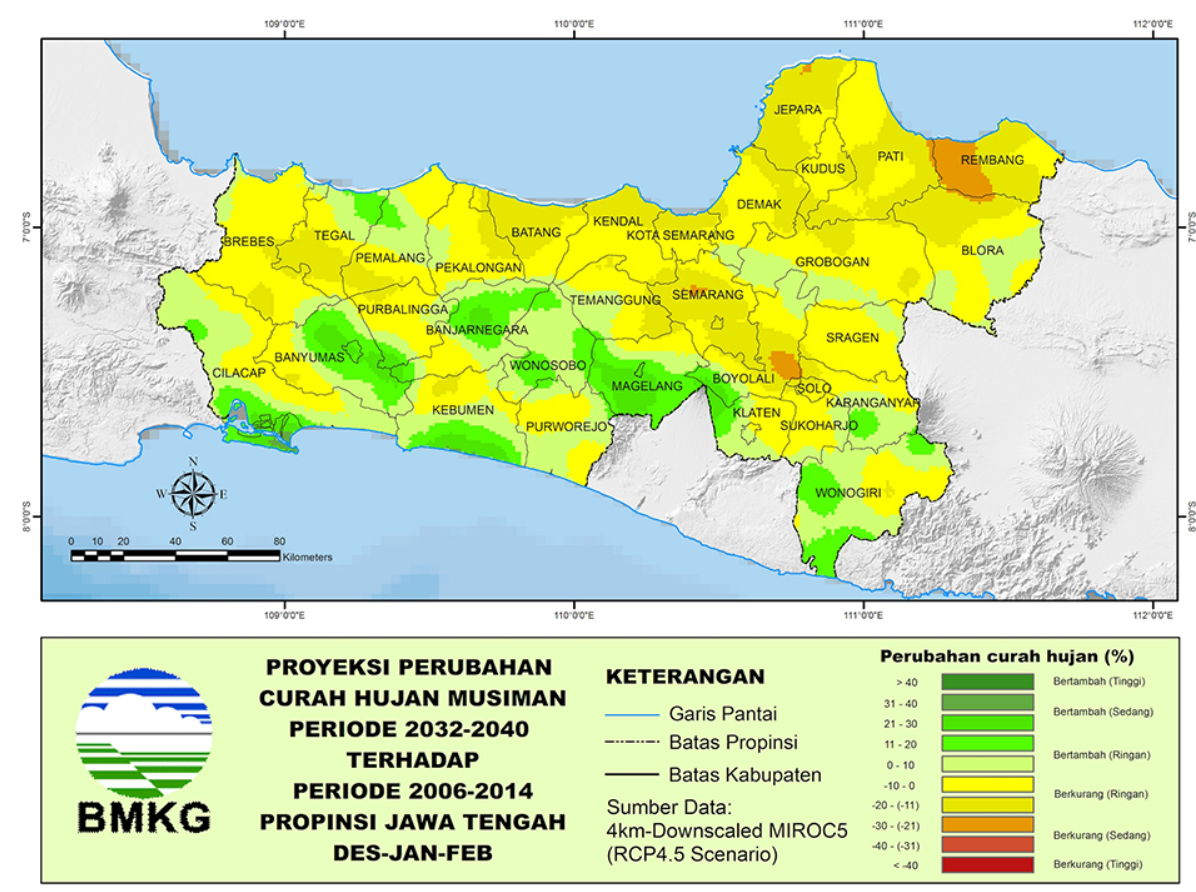

Figure 10. Projected Changes in Rainfall for the Period of 2032 - 2040 (Source BMKG)

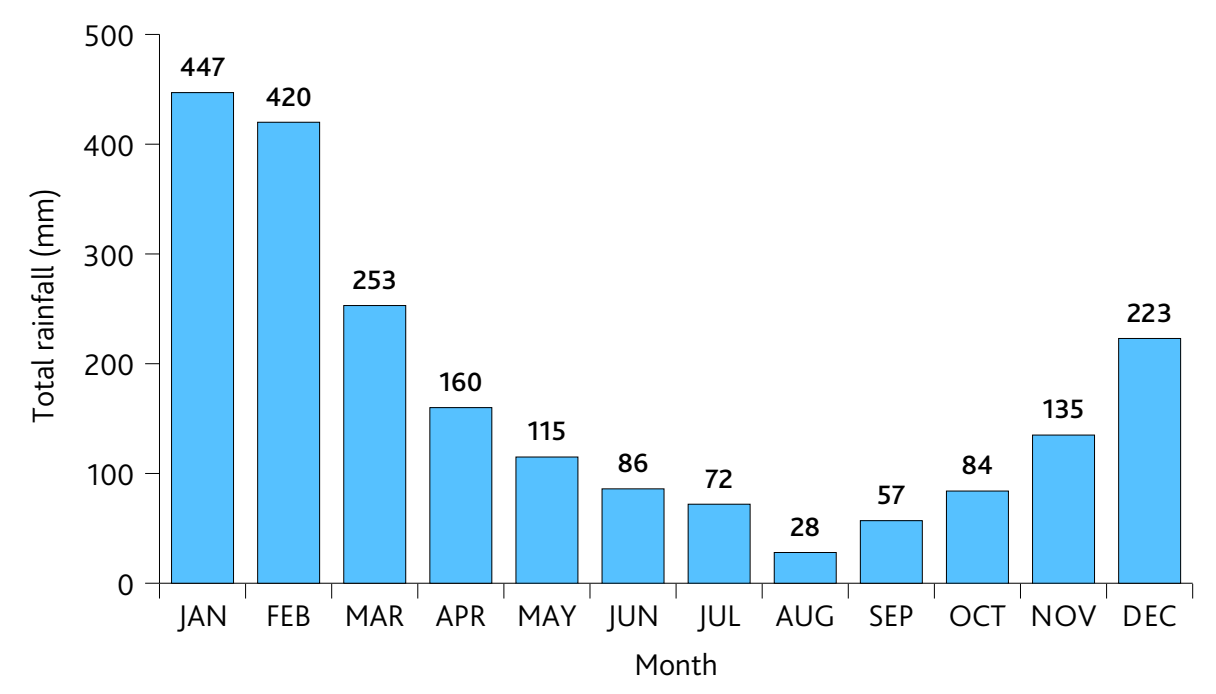

Figure 11. Rezim of Monthly Average Rainfall in Pekalongan Region (2000-2019 Period)

tral Java has a monsoonal climate. In the monsoonal rainfall pattern, the region has a clear difference between the rainy season and the dry season. In general, the dry season lasts from April to September and the rainy season from October to March.

Tidal flooding is expected to continue to increase both in frequency and in height in the future, in line with the tidal floods are expected to continue to increase only because of the likely climate change trend to be ongoing or so. Changes in rainfall patterns will affect the occurrence of flooding in the downstream area of the Kupang watershed (Pekalongan coast). This is due to an increase in the maximum rainfall intensity which tends to be higher and the ability of the soil to infiltrate is very low.

\section{Flood Discharge Analysis}

Hourly rain distribution (rain distribution) is determined by direct observation of the hourly rainfall recording data at stations that have the most influence on the watershed. If available, it can mimic the behavior of hourly rain which is similar to the local area at the same latitude and altitude. This distribution is obtained by grouping the rain heights into ranges with certain heights intensity duration frequency (IDF). From the data that has been compiled in the range of rain heights, a design rainfall distribution is selected based on the analysis of the highest frequency and frequency of appearance in the distribution of rain at certain times. The results of the rain distribution in the intensity duration frequency (IDF) in Pekalongan. IDF describes 


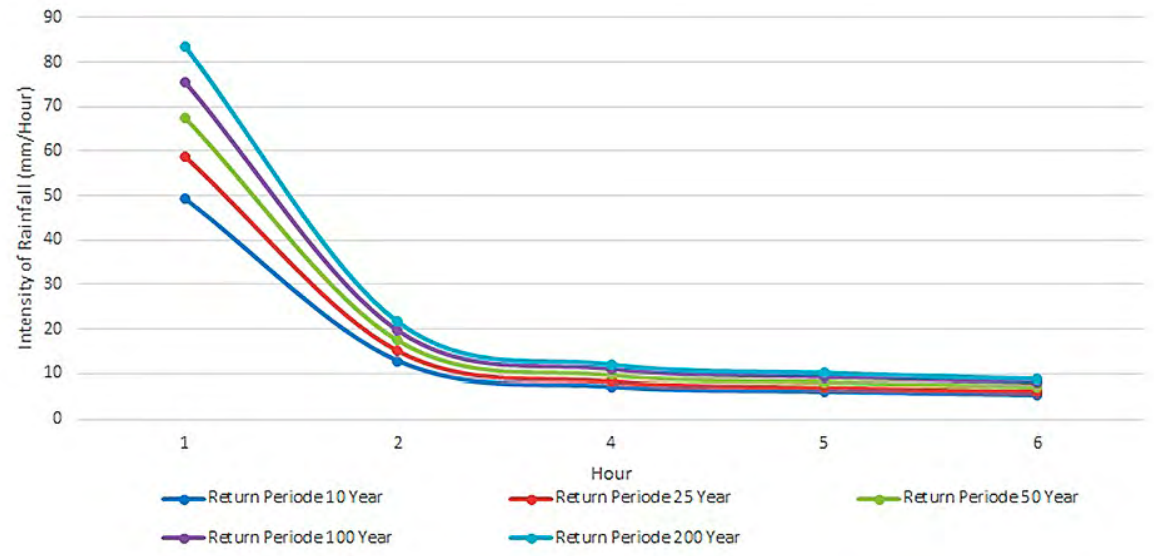

Figure 12. Intensity Duration Frequency in Pekalongan

the value of the number of rain as a function of duration for a certain return period and is very important for the design of hydraulic structures (Overeem, et.al., 2008). The IDF has many drawbacks in hydrology and surface water engineering including in the design of urban drainage infrastructure. IDF graph form can be seen in the following table and figure 12.

Analysis of the planned flood discharge using the Nakayasu Synthetic Unit Hydrograph (HSS) method, this is in accordance with the explanation provided in the methodology. The rain input used is the calculated rain from the Gumbel probability distribution with various return periods as previously analyzed with the focus of the analysis, namely the Kupang watershed with the main river, the Banger River. The results of the calculated flood discharge analysis with various return periods can be seen in the following figure.

Based on the graph above, a 50-year return period was used in modeling the floods in the Kupang watershed, where the Pekalongan River is the main river with a control point at the study location with a planned discharge of $557.23 \mathrm{~m}^{3} / \mathrm{s}$. Based on the analysis of the discharge that enters the Banger river network system, which is about $70 \%$ of the total discharge in the Kupang watershed, so the amount of discharge to be used in the flood modeling is $390.06 \mathrm{~m}^{3} / \mathrm{s}$.

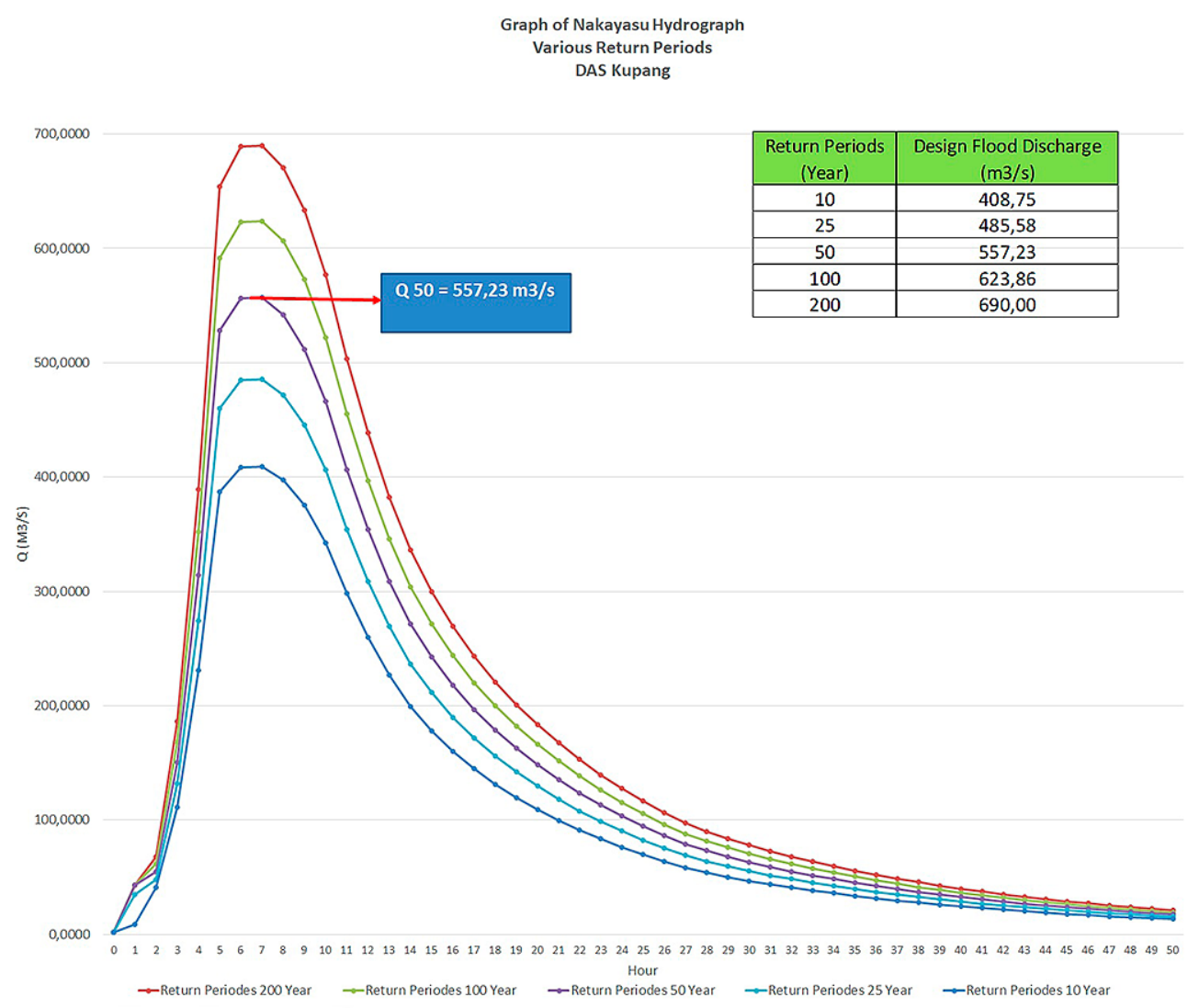

Figure 13. Flood Discharge Graph Planned Various Return Periods 


\section{Hydraulic Flood Two Dimensional Model}

The distributed model is generally used to investigate the effects of land cover change on flood discharge due to urbanization. The model must have sufficient spatial data parameters to resemble actual conditions and to achieve good accuracy (Fardi et.al., 2011). Unfortunately, most developing countries have limited and inadequate datasets. Circumstances can be a problem in distributed flood model simulations. The number of scenarios that must be developed and analyzed is so complex that a simple numerical method is used to calculate the flood area in each scenario.

One of the efforts made is to study the effect of the distribution of flood hydrographs and flood inundation. For the model of flood hazard, it is necessary to do 2D flood flow modeling. Mapping a 2-dimensional flood model is very useful to identify areas that are potentially affected by flooding (Formanek et al., 2013) The input hydraulic model is very important for hydraulic flood modeling. Hydrograph analysis for rivers where there is no or very little flood hydrograph observation, it is necessary to look for the characteristics or parameters of the drainage area first, for example, the time to reach the top of the hydrograph (time to peak magnitude), bottom width, area, slope, the longest channel length (length of the longest channel), runoff coefficient and so on (Siregar, 2016). The resulting solutions represent flood characteristics such as inundation area, inundation depth, and flow velocity Two-dimensional hydraulic analysis using hec-ras software where this modeling is basic modeling to determine the area of inundation that occurs based on hydrological data input in the form of a flood hydrograph. The Result of the analysis is given in the figure below.
The rivers that were carried out by flood discharge modeling were the Pekalongan River and the Banger River. From the results of the flood modeling, inundation or runoff occurred from the Pekalongan and Banger rivers. The locations affected include Jalan Kusuma Bangsa, Jalan Wr. Supratman, Jl. Panjang Wetan, Jalan Sampangan, Jl. Jranpang, Jl. Trimbing and Jl. Krapyak. To overcome the flood problems above, structural and non-structural efforts are needed. Structural efforts include building infrastructure to deal with floods, such as retention ponds, long-storage, polders, reservoirs. Non-structural efforts made include improving disaster mitigation and outreach to the community around the Pekalongan Coastal Coast. The thing of concern in handling floods around the coast is the presence of tidal conditions that cause back-water around the coast, which impedes the flow to the sea and raises the water level in the upstream. In order for the flood problem to be addressed properly, it is necessary to carry out an integrated solution so that it can be resolved comprehensively.

\section{Coastal Hydrodynamic Model}

Two-dimensional hydrodynamic modeling using Delft-3d software. The boundary conditions used in the modeling are the tides of sea water with the addition of sea level rise and land subsidence in the next 50 years. From the analysis, the increase in water level due to global warming is estimated to be $230 \mathrm{~mm}$ and decrease of land subsidence is $240 \mathrm{~cm}$. This data is used to perform hydrodynamic modeling. Changes in tidal fluctuations can be seen in the table below.

The modeling process is carried out by using the flow module where in this modeling the boundary conditions used are astronomical boundary require-

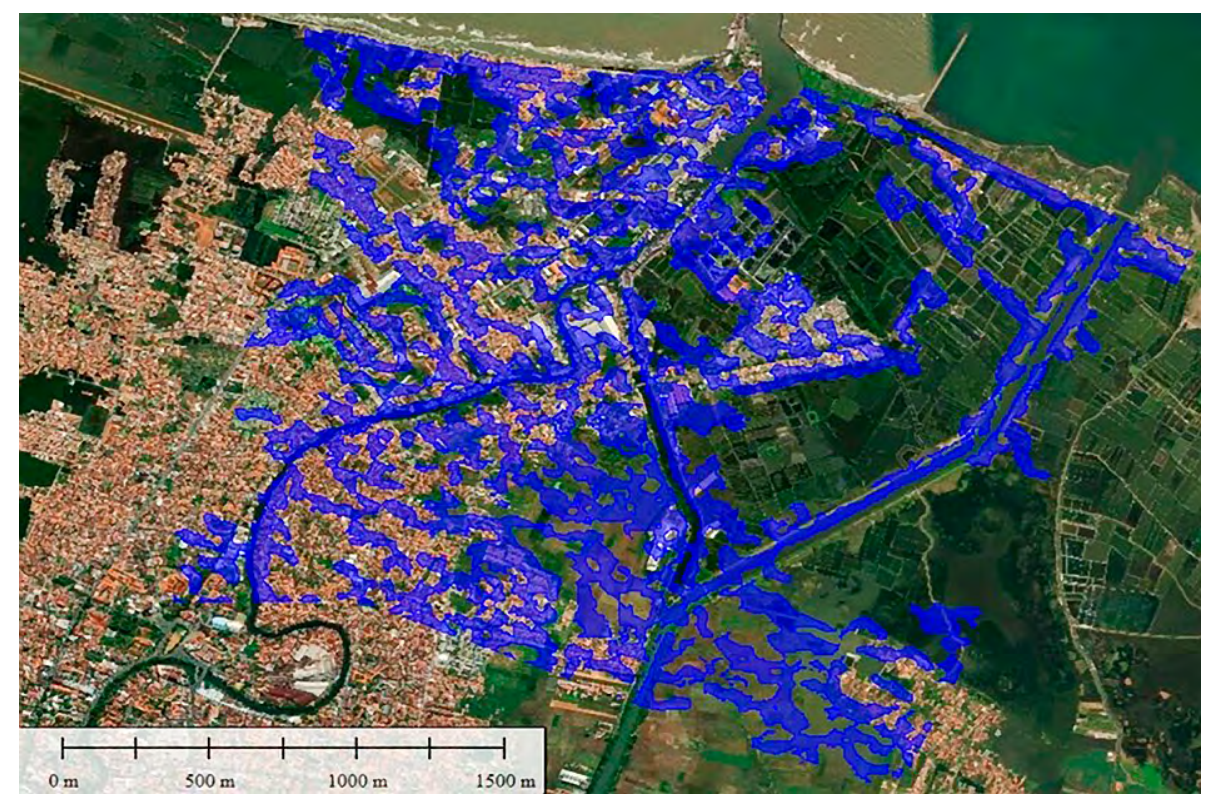

Figure 14. The Result of hydraulic flood two dimentional modelling in Pekalongan Coastal 


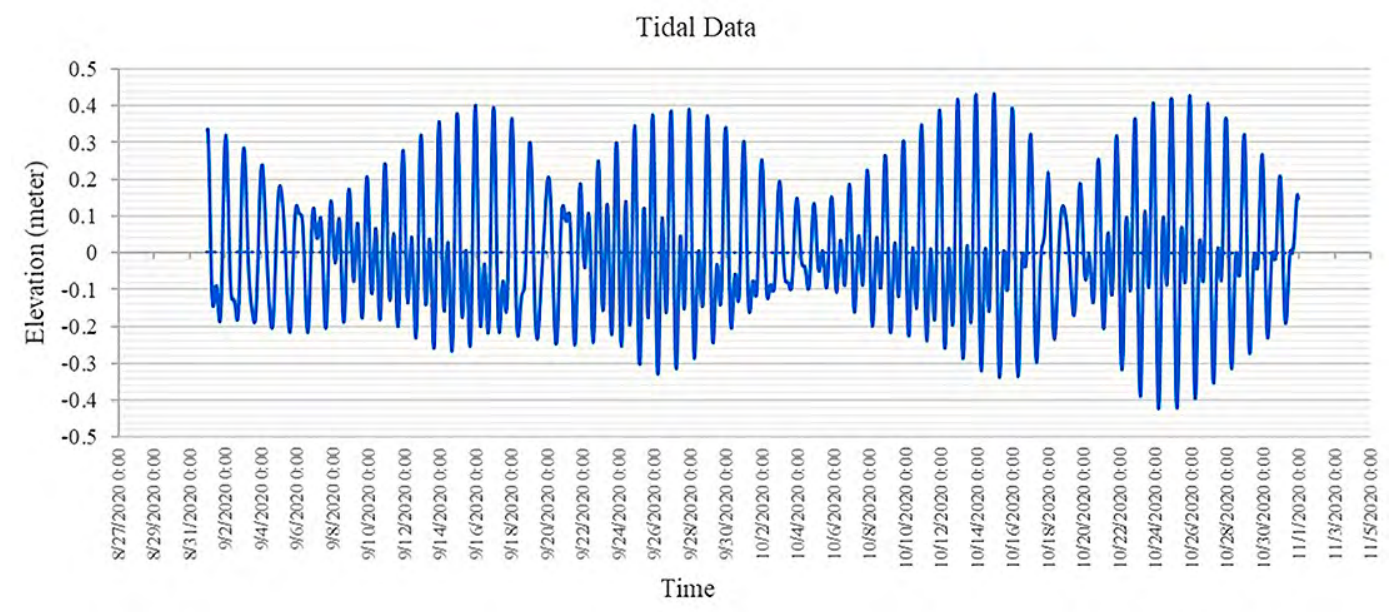

Figure 15. Tidal Data Used

ments which describe the fluxutation of sea level at high tide and low tide. From the results of the analysis carried out, it can be seen in the image below that at the moment the coastal area of Pekalongan is still safe against sea water, for the next 50 years based on sea
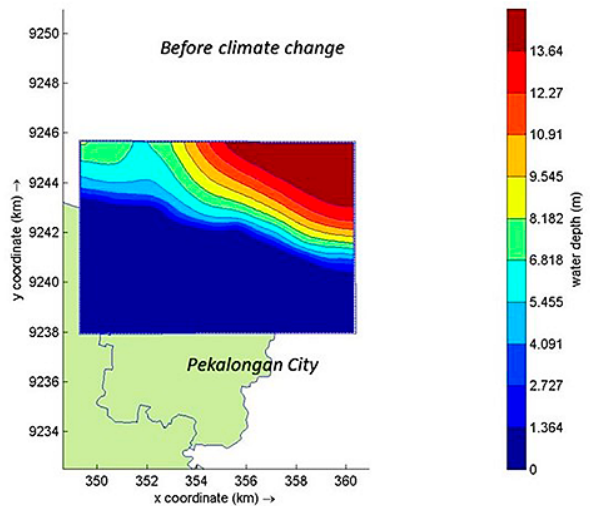

The Simulation is using hydrodynamic model DELFT-3D :

(a) Before Climate Change and Land-Subsidence ; (b) After Climate Change and Land-Subsidence (50 th years from 2020)
Environment, the existing infrastructure arrangement in Pekalongan which refers to eco green infrastructure will certainly have an impact on the environment which includes conservation, prevention of water pollution, preserving biota and preserving the

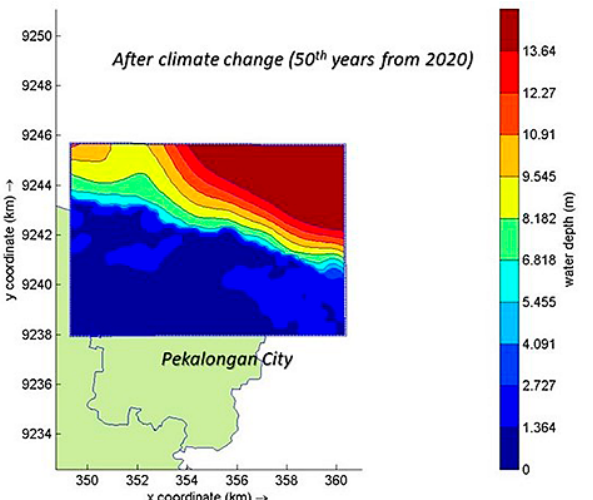

Figure 16. Result of Hydronynamic model before and After Climate Change and Land Subsidence

level rise and land subsidence, several coastal areas of Pekalongan are inundated by tides. From the modeling results, the coastal area of Pekalongan is very vulnerable to sea level rise in the future. In addition, with flooding due to higher flood discharge due to changes in land use, the flood inundation in the coastal area has become wider not only in the coastal area but to the upstream coastal area around Pekalongan City. This condition is the basis for how structural efforts are made to solve these problems.

\section{Coastal Hydrodynamic Model}

The concept of sustainable development in the arrangement of the Pekalongan coastal area through the development of integrated tidal flood control infrastructure, can be explained as follows:

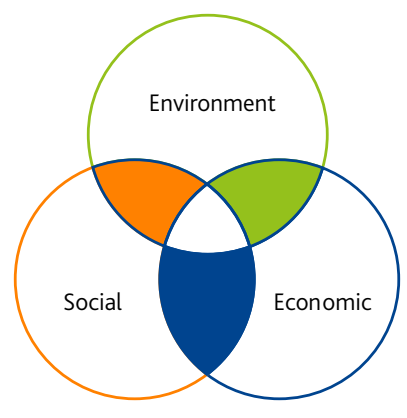

Figure 17. Three aspects of sustainable development environment, preventing destruction. water which has an impact on the environment, reduces air pollution or increases in $\mathrm{CO}_{2}$ and so on.

Economic, structuring existing infrastructure in Pekalongan from an economic perspective, to increase revenue from the Pekalongan Regional Budget, namely through the use of embankments / embankments as an outer ring road that can contribute to economic recovery, the use of polders as conservative reservoirs that can be used as tourist attractions, greenbelt areas or Green areas that can be used as agricultural or plantation land which are useful for increasing production yields so as to restore the economy, development of resorts and cafes around the coast also supports economic improvement. 
Social perspective, the existing infrastructure arrangement in Pekalongan will establish coordination between the local government and the community towards the environment. One example is the formation of a Green Community which is mutually beneficial to the local government. In addition, there is empowerment of human resources that occurs in the surrounding community, namely by involving the surrounding community in the management of tourism, fisheries and other related fields.

The involvement of all relevant stakeholders is also needed in the handling of the Pekalongan coastal tidal flood. Holistic coordination also means that all problems of damage and environmental management of the coastal areas of Pekalongan must be the responsibility of all parties (government, NGOs, communities, and individuals) and all regions (whether local, regional, national). The responsibility of the regional head moves all stakeholders to realize the vision and mission of the region through the Pekalongan coastal area arrangement policies, strategies and programs, both short and long term. So that the problem of tidal flooding on Pekalongan Beach can be resolved with holistic policies both structurally and non-structurally.

\section{Design Concept}

\section{Alternative 1}

The concept of alternative flood management 1 in the Pekalongan area that will be carried out is a physical treatment that aims to limit the tidal inflow towards the mainland, create temporary storage of water from the land that should be wasted downstream, periodically pump the stored water downstream and increase the river storage capacity by making embankments.
The concept of alternative flood management 1 can be seen in the following figure 18 .

Physical development that requires handling include:

- Making a dike separating land and sea areas

- Making longstorage / carrying channel parallel to the tidal floods separation dike

- Utilization of pumps requires a larger and optimal capacity so that the tidal flood inundation area can be immediately pumped into long storage and retention ponds as water storage and will be pumped when the river water level has receded.

- Making river embankments and / or raising sungi parapets which are still not high enough

- Perform river normalization, especially in the river estuary area

- Making drain collectors at several locations which are at a lower elevation than the tide level. A pumping system is needed in this area so that stagnant water can be channeled into rivers / sea.

\section{Alternative 2}

The tidal flood handling concept in alternative 2 adopts a waterfront city concept that is integrated with regional development planning to support economic improvement on the coast of Pekalongan through integrated area development such as tourism, raw water storage, industrial, sports, business areas and residential areas. The objective of this alternative design is to protect the coastal area of Pekalongan from the threat of tidal flooding and environmental degradation. Through this design concept, it is hoped that several main issues related to problems in the coastal area of Pekalongan, such as the threat of tidal flooding, land subsidence, limited raw water, and

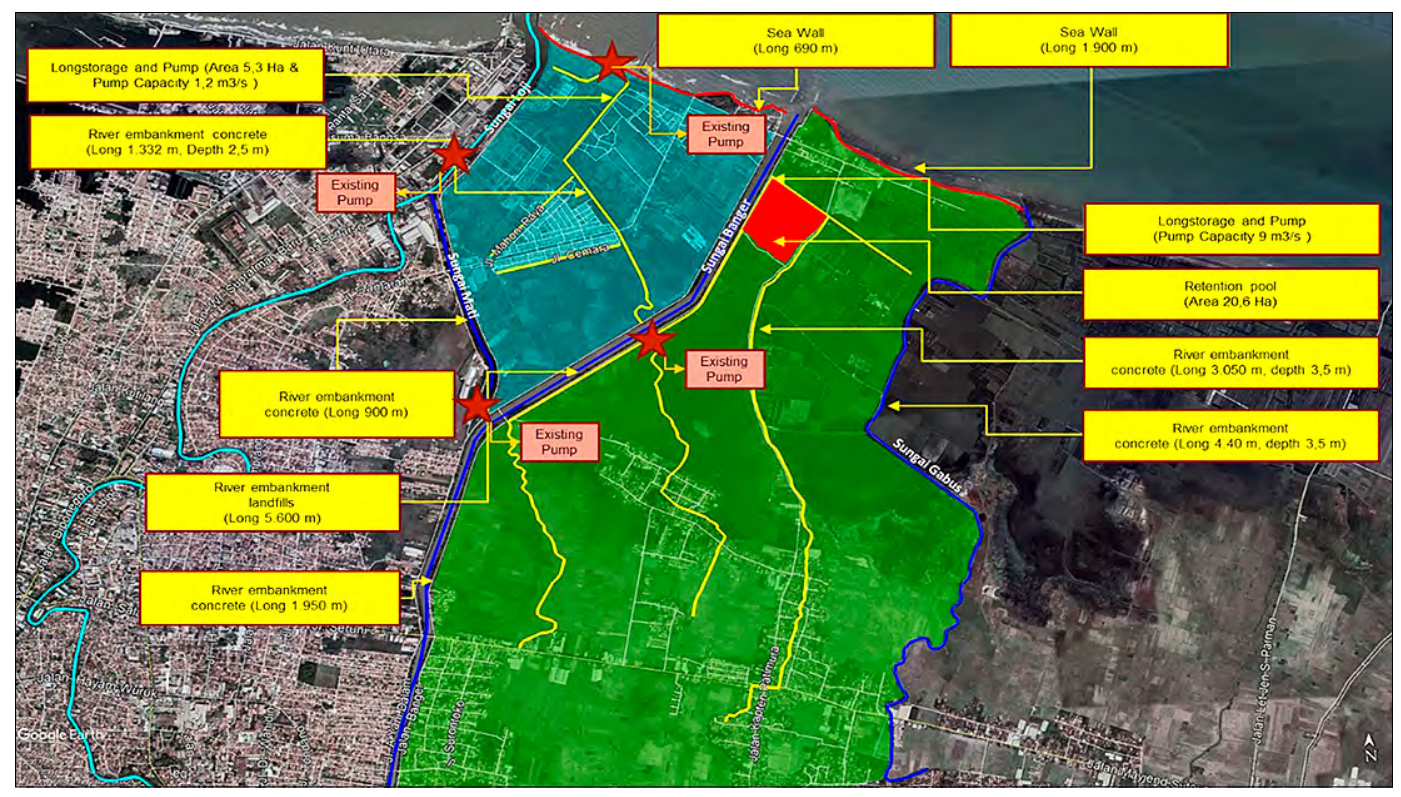

Figure 18. Design Concept (Alternative 1) 


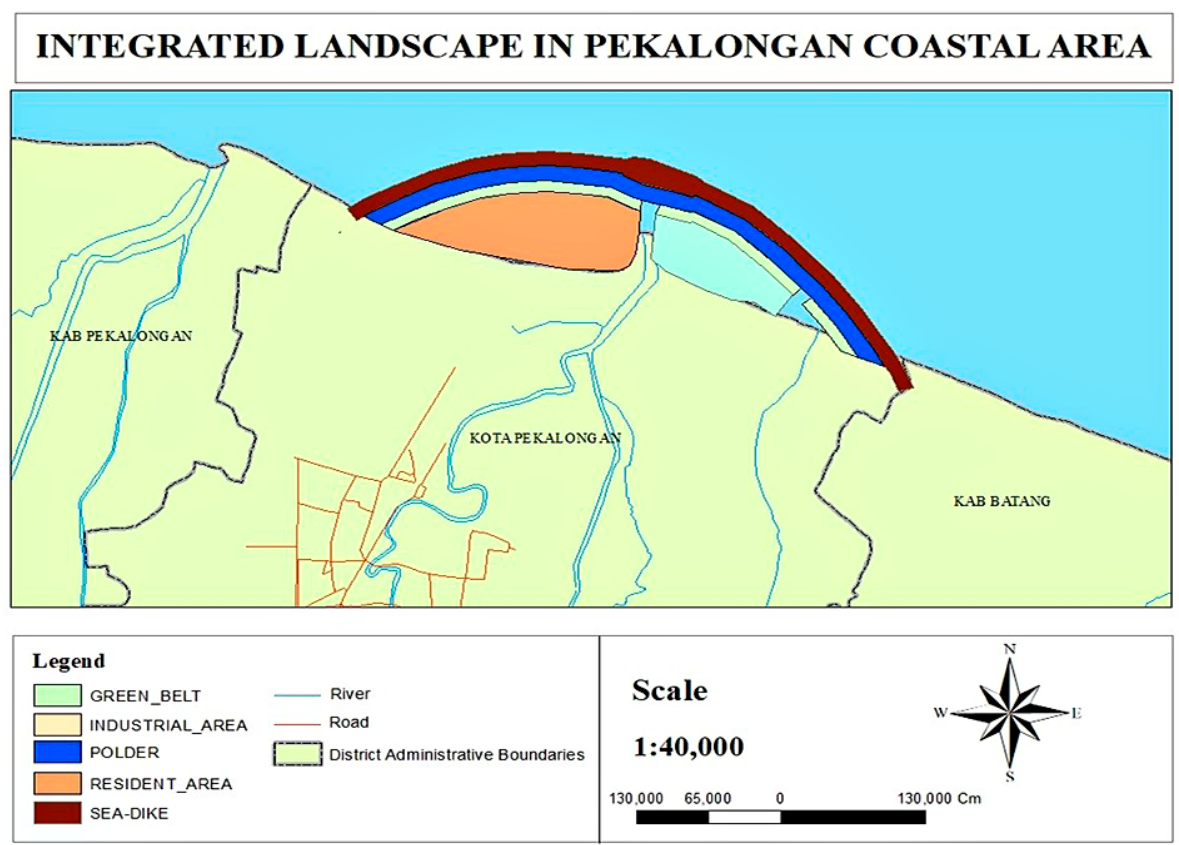

Figure 19. Layout Map of Pekalongan Tidal Floods Management Concept Design (Alternative 2)

the arrangement of the transportation and settlement system can be resolved. Based on the concept previously described, there are several stages in realizing a waterfront city on the coast of Pekalongan, namely:

1. Construction of sea embankments and river estuaries

2. Construction of sea reservoirs, floodgates and construction of pumping stations

3. Reclamation of coastal areas that can be utilized as an integrated residential area or business area

4. Development of supporting infrastructure, roads and bridges connecting areas, residential areas and business areas located on reclaimed land.
The real condition design concept for alternative 2 can be seen as shown below.

Explanation related to the Pekalongan flood handling design concept Alternative 2:

1. The arch is the outermost part of the arc of sea dikes or levees sea which can be used as an outer ring road or road travel with a primary function as a sea dike protecting sea water runoff, overtopping or may overcome the tidal flood

2. The polder can be used as a reservoir for raw water originating from the Banger River and the Loji River and separated by a water gate on the middle side

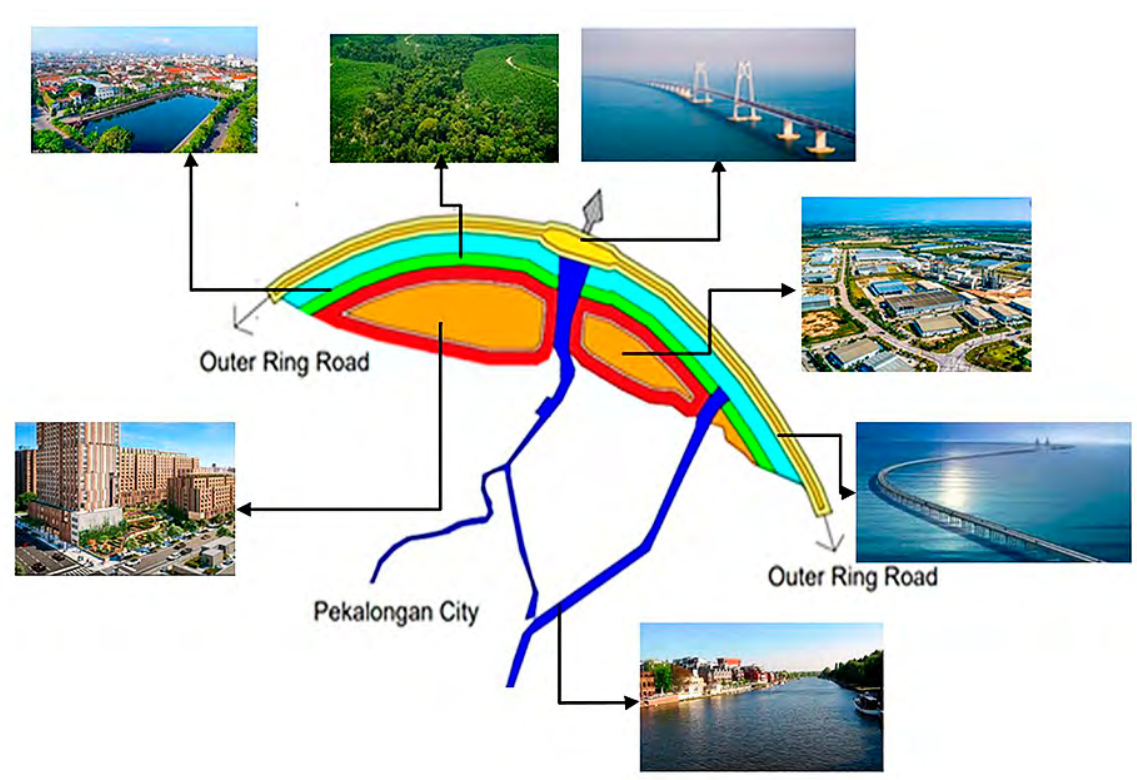

Figure 20. Design Concept for Tidal Floods Pekalongan Flood Management (Alternative 2) 
which is a canal that functions as a channel for fishermen to enter and exit.

3. Green belt area or green area that is used for protection of the environment, conservation of water, fisheries and is useful as a tourist spot, namely a mangrove tourism park.

4. Residential areas that use green roofs and green walls which aim to create buildings that are environmentally friendly as well as Industrial, Sport and Business Areas such as those aimed at improving the economy of the Pekalongan community.
Alternative Design Concept Philosophy 2:

The concept of structuring forms an arc which has a philosophy, which is to symbolize the stability realized through sustainable development that is able to improve the economy and symbolizes conformity to targets which can be seen from the existence of regional arrangement designs and infrastructure development in accordance with existing quality standards. The Handling Design Concept can be seen as shown below.

\section{Conclusion}

During the last 20 years there has been an increase in temperature around the north coast of Pekalongan by one degree Celsius. This will certainly have an impact on increasing sea level on the coast of Pekalongan. The increase in maximum daily rainfall during the last twenty years has also occurred in the Kupang watershed, which is the chatcment area of the Pekalongan River. Both of these can increase the incidence of flooding in the downstream watershed or the coast of Pekalongan. The total area of the tidal flood inundation that occurred was 458.3 ha, with inundation heights varying from twenty centimeters to one meter.

The results of the flood modeling show that there are flooded areas, especially in areas around river flow, particularly in areas affected by tides. One thing of concern in handling floods around the coast is the presence of tidal conditions that cause back water around the coast, thus obstructing the flow to the sea and raising the water level in the upstream. In or- der for the flood problem to be resolved, an integrated solution is needed so that it can be resolved comprehensively.

Regarding the two design alternatives that we present, there are several considerations in choosing the right alternative in solving the tidal flood problem on Pekalongan beach. In choosing alternative 1 , it is necessary to pay attention to operations related to operation and maintenance of flood pumps. If the flood pump experiences problems or does not function optimally, then the flood management in the coastal area of Pekalongan cannot be handled optimally. So it requires human resources as operators who are able to operate and maintain flood pumps properly, as well as public concern to protect the environment from waste problems. If using alternative design 2 to solve the problem of tidal flooding in Pekalongan, it does not require much operation and maintenance. but the consequences are large costs at the beginning of development.

\section{References}

Formánek, A., Silasari, R., Kusuma, M. S. B., \& Kardhana, H. (2013). Two-dimensional Model of Ciliwung River Flood in DKI Jakarta for Development of the Regional Flood Index Map. Journal of Engineering and Technological Sciences, 45(3), 307-325.

Edvin, A. (2011). Climate Change Adaptation and Mitigation in Indonesia. Jakarta: Meteorology Climatology and Geophysics Agency.

Meteorological, Climatological, and Geophysical Agency (2020). Climate Change Projections in Indonesia. Jakarta.

Brunner, G.W. (2016). HEC-RAS, River Analysis System Hydraulic Reference Manual. Washington DC: US Army Corps of Engineers Hydrologic Engineering Center (HEC).
IPCC (2007). Climate Change. Impacts, Adaption and Vulnerability. New York: Cambridge University Press.

IPCC (2020). Seminar Presentations of Indonesia's Achievements in Addressing Climate Change. Directorate of Climate Change Mitigation, Ministry of Environment and Forestry. Jakarta: Republic of Indonesia.

Farid, M., Mano, A., \& Udo, K. (2011). Distributed flood model for urbanization assessment in a limited-gauged river basin. WIT Transactions on Ecology and the Environment, 146, 83-94.

Kusuma, M. S. B., Kuntoro, A. A., \& Silasari, R. (2011). Preparedness effort toward climate change adaptation in Upper Citarum river basin, West Java, Indonesia. Society for Social Management Systems Internet Journal, 78, 1-7. 
Kusuma, M. S. B., Farid, M. \& Marlina, A. (2014). Fluid Dynamics Application For Improving The Performance Of Flood Control System. AIP Conference Proceeding 2014 (pp. 100009-1 - 100009-11), Surakarta: Indonesia

Meiviana (2015). The Earth Is Hotter - Threats of Climate Change in Indonesia. Universitas Gadjah Mada: Online Public Acces Catalog (OPAC).

Ministry of Public Works and Public Housing of the Republic of Indonesia. (2015). Regulation of the Minister of Public Works and Public Housing No. 04 of 2015 concerning Designation of River Areas. pp. 14.

Overeem, A., Buishand, A., \& Holleman, I. (2008). Rainfall depth-duration-frequency curves and their uncertainties. Journal of Hydrology, 348(1-2), 124-134.

Irawan, P., Sari, N. K., Hidayat, A. K., Nursani, R., \& Hendra, H. (2020). Bandingan HSS Snyder-Alexeyev, Nakayasu Dan Gamma 1 Pada Analisis Banjir Sub Das Ciliung Untuk Perencanaan Bangunan Air [Comparison of HSS Snyder - Alexeyev, Nakayasu and Gamma 1 on Ciliung Sub-Watershed
Flood Analysis for Water Development Planning]. Jurnal Siliwangi Seri Sains dan Teknologi, 6(1), 1320.

Regional Development Planning and Research and Development Agency of Pekalongan Regency. (2018). Flood and Tidal Floods Handling Strategies, Policies and Programs in Pekalongan Regency. Consultant Report. Pekalongan, Indonesia

River Basin Organization Pemali Juana. (2017). Pekalongan Flood Management Planning System Report. Consultan Report. Semarang, Indonesia

Sarminingsih, A. (2013). Flood Control Performance Evaluation At Upper Citarum, West Java, Indonesia. Proceedings of the Second International Conference on Sustainable Infrastructure and Built Environment, ITB, Bandung, pp. 275-287.

Delft-3d (2014). Simulation of multi-dimensional hydrodynamic flows and transport phenomena, including sediments. Deltares: The Netherlands.

Irnandi, S. R. (2016). Study of the Contribution of Subwatershed Flood Hydrograph Contribution to the Upper Citarum Watershed. (Unpblished thesis dissertation). Bandung Institute of Technology, Bandung. 